\title{
Elimination of Ritodrine in Mothers Pregnant with Twins and Their Neonatal Twins
}

\author{
Satoko FUJIEDA ${ }^{* 1}$, Mitsuaki KEIRA ${ }^{* 1}$, Mayuko SOMA*2, Yoichi SASAKI ${ }^{* 2}$, Ainari KONDA*3, \\ Yuji MUKAI*3, Takaki TODA*3, Nobuo INOTSUME ${ }^{* 3}$ and Hiroshi YOSHIDA*1
}

\begin{abstract}
This study aimed to clarify the individual elimination kinetics of serum ritodrine in women pregnant with twins and their twin neonates. Serum ritodrine concentrations in 10 twin pregnant women and their twin neonates were measured by liquid chromatography-tandem mass spectrometry (LC-MS/MS) using 100 $\mu \mathrm{L}$ of serum. The ritodrine elimination half-life in mothers was $5.0 \pm 2.2(3.7-11.1) \mathrm{h}[$ mean $\pm \mathrm{SD}($ range $)]$, while the halflives of ritodrine in the first and second newborns were 9.0 8.4(4.2-29.6) and 7.2 $\pm 4.3(4.3-13.2) \mathrm{h}$, respectively. Large individual differences in the half-life of ritodrine were observed in both mothers and their newborns. Since ritodrine remained in newborn serum for 24-48 $\mathrm{h}$ after birth, newborns need to be carefully monitored for ritodrine-related complications during this period.
\end{abstract}

Key words : ritodrine, serum ritodrine concentration, twin pregnancy, half-life of ritodrine

Jpn J Clin Pharmacol Ther. 2017; 48(3) : 91-94

\section{Introduction}

In 2013, the European Medicines Agency placed a restriction on the duration ritodrine treatment in pregnancy, recommending that ritodrine, a selective $\beta_{2}$ agonist, should be given for shortterm management of up to " 48 hours between 22 to 37 weeks of gestation”. The report also described cardiovascular adverse reactions caused by the residual $\beta_{1}$ agonist activity of ritodrine. ${ }^{1)}$ In Japan, premature labor is treated with long-term tocolysis, with the goal to maintain pregnancy. ${ }^{2)}$ Ritodrine is frequently used as a uterine contraction suppressant in threatened premature labor. ${ }^{3,4)}$ In Japan, long-term tocolysis is the treatment of choice in cases of threatened premature labor. ${ }^{5,6)}$ The Japan Society of Obstetrics and Gynecology defines threatened premature labor as potential labor occurring between 22 and 37 weeks of gestation. ${ }^{7)}$ In order to maintain pregnancy, patients are treated with ritodrine, and administration is started and continued from the mid-term in some cases. Therefore, understanding the pharmacokinetics of ritodrine in pregnant women and their newborns is essential to ensure that the treatment is safe and effective. In Japan, ritodrine is the drug of choice for long-term tocolysis used to prevent threatened premature labor. As ritodrine can pass through the placenta to the fetus, complications in newborns have been reported in Japan. ${ }^{8-10)}$ In the present study, we examined individual differences in the elimination of ritodrine used for treating threatened premature labor in mothers pregnant with twins and their newborns.

\section{Materials and Methods}

\section{Subjects}

Mothers hospitalized for threatened premature labor between February 2011 and March 2013 were enrolled in the study. Of the 10 mothers studied, three had diamniotic-monochorionic twins and seven had diamniotic-dichorionic twins. All subjects maintained pregnancy until week 32 or longer, with four maintaining pregnancy for less than 35 weeks. The average length of pregnancy was 35.3 (range: $33.4-37.0$ ) weeks. All 20 newborns exhibited low birth weight of 2100 (range: 18442702)g on average.

The duration of continuous ritodrine infusion ranged from 13 to 147 days, with an average of 55 days. Except one woman who continued ritodrine infusion until week 37 of pregnancy, administration of ritodrine was discontinued for medical reasons before delivery in all other women (Table 1).

The study protocol was based on a research plan approved by the Ethics Committee of Tenshi Hospital. All enrolled participants were mothers pregnant with twins who provided informed consent for themselves and for their newborns.

\section{Measurement of Serum Ritodrine Concentration}

Left over serum samples collected for daily routine biochemical testing were used for measurement of serum ritodrine concentration. Serum samples were stored at $-20^{\circ} \mathrm{C}$ until analysis. Ritodrine concentrations were determined using a previously developed method. ${ }^{11)}$ Stable isotope labeled ritodrine- $\mathrm{d}_{4}$ was used as the internal standard and added to $100 \mu \mathrm{L}$ of serum (final concentration: $10 \mathrm{ng} / \mathrm{mL}$ ). Subsequently, $100 \mu \mathrm{L}$ of $0.1 \mathrm{M}$ sodium carbonate buffer $(\mathrm{pH} 9.75)$ and $1 \mathrm{~mL}$ of ethyl acetate were added. After centrifuging the mixture for $10 \mathrm{~min}$ at 13,000

\footnotetext{
${ }^{* 1}$ Department of Obstetrics and Gynecology, Tensi Hospital, Japan $\quad{ }^{* 2}$ Department of Pharmacy, Tenshi Hospital, Japan $\quad{ }^{* 3}$ Division of Clinical Pharmacology, Hokkaido Pharmaceutical University School of Pharmacy, Japan

Address for correspondence: FUJIEDA S. Department of Obstetrics and Gynecology, Tenshi Hospital, N12-E3-1-1 Higashiku Sapporo, Hokkaido 065-8611, Japan_E-mail: fujie3105@gmail.com

Manuscript received October 21, 2016; revised January 18, 2016; accepted January 19, 2016

ISSN 0388-1601 Copyright: (C2017 the Japanese Society of Clinical Pharmacology and Therapeutics (JSCPT)
} 
Table 1 Characteristics of twin pregnancies

\begin{tabular}{|c|c|}
\hline Category & Mean \pm SD (Range $)$ \\
\hline Subjects & 10 \\
\hline Age (yrs) & $32.2 \pm 4.5 \quad(26.0-39.0)$ \\
\hline Weight (kg) & $59.6 \pm 5.0(53.3-70.4)$ \\
\hline $\begin{array}{r}\text { Delivered Week of pregnancy } \\
\text { (weeks) }\end{array}$ & $35.3 \pm 1.2(33.4-37.0)$ \\
\hline $\begin{array}{c}\text { Duration of Ritodrine infusion } \\
\text { (days) }\end{array}$ & $54.5 \pm 37.3(13.0-147.0)$ \\
\hline $\begin{array}{r}\text { Ritodrine infusion rate } \\
(\mu \mathrm{g} / \mathrm{kg} / \mathrm{min})\end{array}$ & $2.92 \pm 0.84(0.88-3.80)$ \\
\hline Number of newborns & 20 \\
\hline Weight of first newborn (g) & $2100 \pm 204(1844-2474) 7$ \\
\hline Weight of second newborn $(\mathrm{g})$ & $2016 \pm 342(1536-2702)$ \\
\hline
\end{tabular}

rpm, $800 \mu \mathrm{L}$ of the ethyl acetate layer was evaporated to dryness at $40^{\circ} \mathrm{C}$ for $1 \mathrm{~h}$. After dissolving the residue in $100 \mu \mathrm{L}$ of water, $5 \mu \mathrm{L}$ was injected into an LC-MS/MS system (API 3200 Q Trap System, AB Sciex, USA). An Ascentis Express C18 $(3 \mathrm{~cm} \times 2.1$ mm, particle size $2.7 \mu \mathrm{m}$; Supelco D, USA) column was used at room temperature. The mobile phase consisted of $\mathrm{AcCN} / \mathrm{H}_{2} \mathrm{O}$ / $\mathrm{HCO}_{2} \mathrm{H}(50 / 50 / 0.1)$ at a flow rate of $0.1 \mathrm{~mL} / \mathrm{min}$. A Turbo Ion Spray Interface was used in the positive ion mode (MRM), with analysis by multiple reaction monitoring (MRM). The software used for the LC-MS/MS system was Analyst ver. 1.4.2 (ABScix). The lower limit of quantification for this method is $0.3 \mathrm{ng} / \mathrm{mL}$.

\section{Pharmacokinetic Analysis}

In this study, blood concentrations in samples collected after at least $48 \mathrm{~h}$ of continuous ritodrine infusion were considered to have reached steady state. ${ }^{12}$ The serum concentration was measured at steady state between 1 and $5 \mathrm{~h}$ before termination of ritodrine infusion. ${ }^{8)}$ A one-compartment model was used for pharmacokinetic analysis of ritodrine. The serum concentration measured was used to calculate total body clearance (Equation 1). The half-life of ritodrine was calculated (Equations 2 and 3) using the same serum concentration used to calculate total body clearance as well as serum concentrations at $48 \mathrm{~h}$ following delivery. The ritodrine volume of distribution was calculated using total body clearance and elimination rate constant (Equation 4). The half-life of ritodrine in newborn was calculated using serum concentration in the umbilical cord blood and serum concentrations measured at 10-24 h after birth(Equations 2 and $3)$. We also calculated the maternal to fetal transfer rate of ritodrine (Equation 5).

$$
\begin{array}{ll}
\mathrm{CL}=\mathrm{k}_{0} / \mathrm{C}_{\mathrm{ss}} & (\text { Equation 1) } \\
\mathrm{ke}=(\ln \mathrm{C} 1-\ln \mathrm{C} 2) /(\mathrm{t}(\mathrm{C} 2)-\mathrm{t}(\mathrm{C} 1)) & (\text { Equation 2) } \\
\mathrm{t}_{1 / 2}=0.693 / \mathrm{ke} & \text { (Equation 3) } \\
\mathrm{Vd}=\mathrm{ke} / \mathrm{CL} & \text { (Equation 4) }
\end{array}
$$

where CL is total body clearance $(\mathrm{L} / \mathrm{kg} / \mathrm{h}), \mathrm{k}_{0}$ is dosage rate ( $\mathrm{ng} / \mathrm{kg} / \mathrm{min}), \mathrm{C}_{\mathrm{ss}}$ is steady state serum concentration, $\mathrm{Vd}$ is apparent volume of distribution $(\mathrm{L} / \mathrm{kg}), \mathrm{t}_{1 / 2}$ is elimination halflife $(\mathrm{h})$, and ke is elimination rate constant $\left(\mathrm{h}^{-1}\right) . \mathrm{C}$ is serum concentration $(\mathrm{ng} / \mathrm{mL})$ at a specific time $\mathrm{t}(\mathrm{h})$.
Transfer Rate $=$ cord blood ritodrine concentration/ritodrine concentration at the time of delivery estimated from elimination half-life $\times 100($ Equation 5).

Statistical analysis was performed using Student's t-test, with the level of statistical significance set at $5 \%$.

\section{Results}

Table 2 shows the pharmacokinetic data of the 10 mothers pregnant with twins. There was a negligible difference in serum ritodrine concentration with respect to the number of chorions. Upon constant continuous infusion of ritodrine at a dose of [mean \pm standard deviation (range) ] 2.29 $\pm 0.84(0.88-3.80) \mu \mathrm{g} / \mathrm{kg} /$ $\mathrm{min}$ in the 10 mothers, steady state serum concentration of $117.7 \pm 37.4(53.9-176.4) \mathrm{ng} / \mathrm{mL}$ was achieved, and total body clearance of ritodrine was calculated to be $1.47 \pm 0.33$ (0.98-1.99) $\mathrm{L} / \mathrm{kg} / \mathrm{h}$. Using the serum concentration used to calculate total body clearance and the $19-40^{-} \mathrm{h}$ postpartum serum concentration of $6.3 \pm 8.1(1.8-28.9) \mathrm{ng} / \mathrm{mL}$, the elimination half-life was determined to be $5.0 \pm 2.2(3.7-11.1) \mathrm{h}$ (Figure 1). Using total body clearance and the elimination rate constant, the apparent volume of distribution was calculated to be $7 \pm 5.3$ (6.2-24.7) L/kg.

The 5-min Apgar scores for the 20 newborns after birth ranged from 8-9. Umbilical blood ritodrine concentrations in the 20 newborns were $73.9 \pm 28.1(10.9-104.3)$ and $60.0 \pm 27.0$ $(12.7-101.6) \mathrm{ng} / \mathrm{mL}$ in the first- and second-born twins, respectively (Figure 2). The calculated transfer ratios were 1.12 $\pm 0.26(0.83-1.59)$ and $0.91 \pm 0.19(0.67-1.22)$ for the first and second-born infants, respectively. Since one of the conditions for ethical approval of the study was that serum ritodrine concentrations could only be measured using blood left over from samples collected for the purpose of treatment and diagnosis, and that blood samples could not be analyzed in all newborns. Thus, the half-life of ritodrine could only be calculated for 15 of 20 newborns using umbilical and serum concentrations at $10-24 \mathrm{~h}$ postpartum. The ritodrine half-lives were $9.0 \pm 8.4(4.2-29.6)$ and $7.2 \pm 4.3(4.3-13.2) \mathrm{ng} / \mathrm{mL}$ for the first- and second-born, respectively (Table 2 ).

\section{Discussion}

Information on the administration of ritodrine for threatened premature labor was published in the Pharmaceuticals and Medical Devices Safety Information No. 285 that was released by the Ministry of Health, Labour and Welfare in 2011. ${ }^{13)}$ This release provided information on not only the administration and proper use in mothers, but also discussed the adverse effects that the drug may have on newborns and cautioned on its use in this patient group. ${ }^{13)}$ Although many reports have described the relationship between serum concentration of ritodrine and its effectiveness and complications, there are few reports on the pharmacokinetics of ritodrine in pregnant women and their newborns. ${ }^{2)}$

In our present study, we measured serum concentrations in mothers pregnant with twins, because this group is more likely to receive tocolytic therapy. Furthermore, we were able to thoroughly investigate the pharmacokinetics of ritodrine in both the mothers and their twin newborns. As we speculated, all the subjects in this study did require tocolytic therapy to maintain 


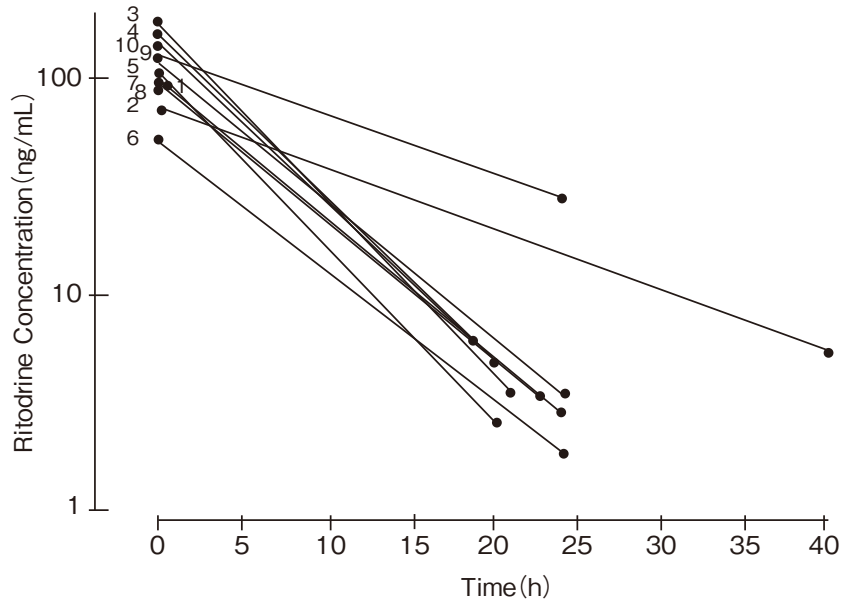

Figure 1 Elimination of ritodrine in ten twin pregnant mothers Numbers in the figure indicate the mother's case number. Relation between time and ritodrine concentration in twin pregnancy mothers. Note : This figure shows the time of disappearance of ritodrine from serum after delivery. There is large individual difference in disappearance of ritodrine.

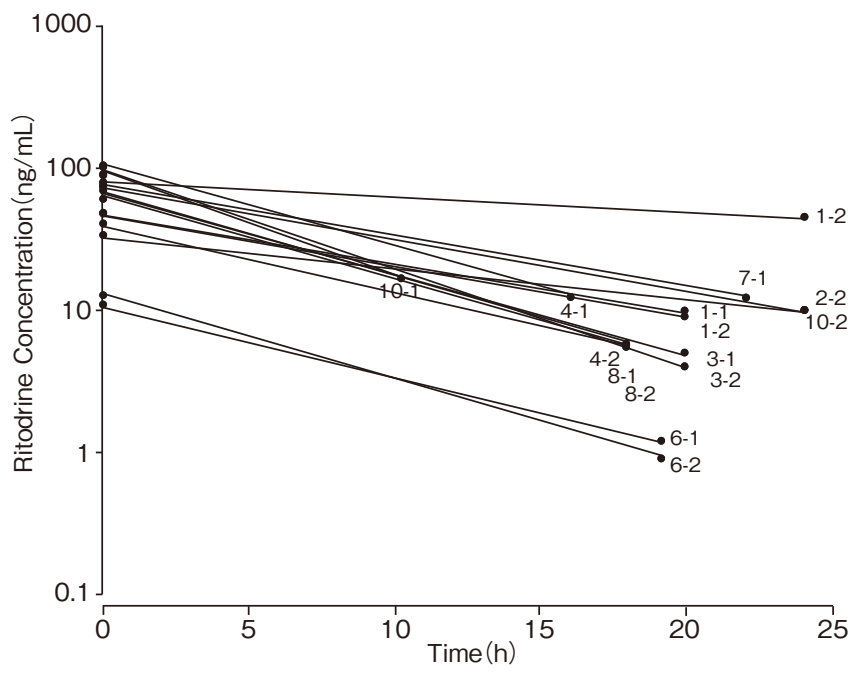

Figure 2 Elimination characteristics of ritodrine in newborns Numbers in the figure correspond to the case numbers shown in Figure 1, and the number following the hyphen indicates the first born $(-1)$ and the second born $(-2)$. Note : Elimination of ritodrine from serum differs between twins.

Table 2 Pharmacokinetic parameters of ritodrine in mothers and their newborns

\begin{tabular}{|c|c|c|c|}
\hline & Cat & & Mean \pm SD (Range $)$ \\
\hline \multirow{5}{*}{ Mother $(n=10)$} & & Dose $(\mathrm{mg} / \mathrm{kg} / \mathrm{h})$ & $0.175 \pm 0.05 \quad(0.053-0.225)$ \\
\hline & & Concentration $(\mathrm{ng} / \mathrm{mL})$ & $117.7 \pm 37.4(53.9-176.4)$ \\
\hline & & Clearance $(\mathrm{L} / \mathrm{h} / \mathrm{kg})$ & $1.47 \pm 0.33 \quad(0.98-1.99)$ \\
\hline & & $\mathrm{t}_{1 / 2}(\mathrm{~h})$ & $5.0 \pm 2.2(3.7-11.1)$ \\
\hline & & $\mathrm{Vd}(\mathrm{L} / \mathrm{kg})$ & $10.7 \pm 5.3(6.2-24.7)$ \\
\hline \multirow{4}{*}{ Umbilical vein } & First newborn $(\mathrm{n}=10)$ & Concentration $(\mathrm{ng} / \mathrm{mL})$ & $73.9 \pm 28.1 \quad(10.9-104.3)$ \\
\hline & & Transfer ratio & $1.12 \pm 0.26(0.83-1.59)$ \\
\hline & Second newborn $(\mathrm{n}=10)$ & Concentration $(\mathrm{ng} / \mathrm{mL})$ & $60.0 \pm 27.0(12.7-101.6)$ \\
\hline & & Transfer ratio & $0.91 \pm 0.19 \quad(0.67-1.22)$ \\
\hline \multirow{4}{*}{ Newborns } & First newborn $(n=8)$ & Concentration $(\mathrm{ng} / \mathrm{mL})$ & $13.5 \pm 13.4(1.2-45.3)$ \\
\hline & & $\mathrm{t}_{1 / 2}(\mathrm{~h})$ & $9.0 \pm 8.4(4.2-29.6)$ \\
\hline & Second newborn $(n=7)$ & Concentration $(\mathrm{ng} / \mathrm{mL})$ & $6.3 \pm 4.1 \quad(1.0-9.6)$ \\
\hline & & $\mathrm{t}_{1 / 2}(\mathrm{~h})$ & $7.2 \pm 4.3(4.3-13.2)$ \\
\hline
\end{tabular}

pregnancy. All participants received continuous ritodrine infusion for a period ranging from 13 to 147 days. With the infusions, all pregnancies were maintained for over 32 weeks (ranging from 33.4-37.0 weeks), which is one of the prognostic indicators used in evaluating newborns. Caritis et al. ${ }^{12)}$ reported that the therapeutic range of serum ritodrine concentration in singleton mothers was $15-45 \mathrm{ng} / \mathrm{mL}$. To maintain twin pregnancy in the present study, the doses required were approximately 4 times the dose reported by Caritis et al. Moreover, steady state concentrations ranged from 53.9 to $176.4 \mathrm{ng} / \mathrm{mL}$, showing great individual difference (Figure 1). Total body clearance of ritodrine in these mothers was $1.47 \pm$ $0.33(0.98-1.99) \mathrm{L} / \mathrm{kg} / \mathrm{h}$. Caritis et al. ${ }^{12)}$ reported that the average total body clearance of ritodrine in singleton mothers was $1.86 \mathrm{~L} / \mathrm{kg} / \mathrm{h}$, and was much higher than that obtained in our twin study.
Ritodrine is mainly metabolized in the liver through sulfate and glucuronide conjugation, ${ }^{14-17)}$ with average total body clearance nearly equal to the rate of the hepatic blood flow. Large individual differences were found for the elimination halflife of ritodrine, which ranged from 4.2 to $29.6 \mathrm{~h}$ in twin neonates. Kuhnert et al. ${ }^{18)}$ demonstrated that the average $t_{1 / 2}$ of ritodrine in neonates was $29.7 \mathrm{~h}$ and was much longer than that obtained in our twin study.

In contrast to an apparent volume of distribution of $7 \mathrm{~L} / \mathrm{kg}$ in pregnant women reported by Caritis et al., ${ }^{12)}$ the average value in the present series was $10.7 \mathrm{~L} / \mathrm{kg}$, which we considered to be widely distributed throughout the body. Figure 1 shows the changes in postpartum maternal serum ritodrine concentration in mothers who delivered twins. In this study, 20-h postpartum levels were obtained in 8 subjects, and 48 -h postpartum levels in 8 subjects. Two cases in our study were within the therapeutic 
range reported by Caritis et al.

In a follow-up survey on neonates born to mothers who were given ritodrine for 3-93 days, Freysz et al. ${ }^{19)}$ reported high safety profile for ritodrine with regard to the cardiovascular and metabolic systems of infants. In addition, other reports examined ritodrine-induced complications in newborns. ${ }^{20,21)}$ We previously reported ritodrine maternal-to-fetal transfer ratios of $1.05 \pm$ $0.23(0.65-1.40)$ and $1.15 \pm 0.26(0.75-1.64)$ in the first- and second-born twins, respectively. ${ }^{8)}$ Table 2 shows similar transfer ratios obtained in the present study.

Our study also found individual differences in elimination half-life calculated from umbilical serum concentration and 4.229.6-h serum concentrations of 15 newborns (Figure 2). As was previously reported for jaundice, there was large individual difference in the development of glucuronide conjugation in newborns. Thus, we speculate that there is also individual difference in metabolism of ritodrine. ${ }^{15,21)}$ There is little information on the transfer of ritodrine through breast milk. However, since the drug having a molecular weight of 326 is a weak base with low protein binding, transfer of ritodrine via breast milk has to be considered. As seen in Case 2(Figure 1), since the elimination half-life was long in the mother, the infants born to this mother showed a clear tendency of prolonged elimination (Figure 2).

To maintain twin pregnancy in the present study, ritodrine serum concentration of approximately $100 \mathrm{ng} / \mathrm{mL}$ was required. Ritodrine remained in the blood for at least $24-48 \mathrm{~h}$ after birth in almost all the newborns, and there were large individual differences in the half-life of ritodrine for both the mothers and their newborns. This study is the first step to describe ritodrine pharmacokinetics in mother and newborn. Further studies including genetic analysis of drug metabolizing enzymes and $\beta$ receptors are required to definitively analyze the cause of ritodrine-induced complications in both mothers and their newborns after birth.

\section{Conflict of Interests}

All authors declare no conflict of interest.

\section{References}

1) Scientific conclusions and grounds for revocation or variation as applicable to the terms of the marketing authorizations and detailed explanation for the differences from the PRAC recommendation. [http: //www.ema.europa.eu/docs/en_GB/document_library/Refer rals_document/Short-acting_beta-agonists/Position_provided_by_ CMDh/WC500153980.pdf. (accessed 2015-2-19) ]

2) Takagi K, Satoh T; Multicentre Premature Labour Study Group. Is long-term tocolysis effective for threatened premature labour? J Int Med Res. 2009; 37 (1) : 227-39.

3) Simhan HN, Caritis SN. Prevention of preterm delivery. N Engl J Med.
2007; 357 (5) : 477-87.

4) The Canadian Preterm Labor Investigators Group. Treatment of preterm labor with the beta-adrenergic agonist ritodrine. N Engl J Med. 1992; 327 (5) : 308-12. doi: 10.1056/NEJM199207303270503.

5) Mercer BM. Preterm premature rupture of the membranes. Obstet Gynecol. 2003; 101(1): 178-93.

6) Minakami H, Sato I. Reestimating data of delivery in multifetal pregnancies. JAMA. 1996; 275 (18) : 1432-4.

7) Nihon Sanka Fujinka Gakkai 2nd. Tokyo. Kanehara \& Co., Ltd., 2008.

8) Soma M, Konda A, Yoshida H, Kishimoto S, Fukushima S, Toda T, et al. Maternal-to-fetal transfer of ritodrine in twin pregnancy. Jpn J Clin Pharmacol Ther. 2012; 43 (5) : 339-43. doi: org/10.3999/jscpt. 43.339.

9) Cotton DB, Strassner HT, Lipson LG, Goldstein DA. The effects of terbutaline on acid base, serum electrolytes, and glucose homeostasis during the management of preterm labor. Am J Obstet Gynecol. 1981; 141 (6) : 617-24.

10) Brazy JE, Little V, Grimm J. Isoxsuprine in the perinatal period. II . Relationships between neonatal symptoms, drug exposure, and drug concentration at the time of birth. J Pediatr. 1981; 98(1) : 146-51.

11) Soma M, Konda A, Fujieda S, Sasaki Y, Takahashi N, Yoshida H, et al. Validation of a novel sensitive method for measuring maternal and neonatal serum ritodrine concentrations. Jpn J Ther Drug Monit. 2013; 30 (4) : 134-41.

12) Caritis SN, Venkataramanan R, Darby MJ, Chiao JP, Krew M. Pharmacokinetics of ritodrine administered intravenously: recommendations for changes in the current regimen. Am J Obstet Gynecol. 1990; $162(2)$ : 429-37.

13) Pharmaceuticals and Medical Devices Safety Information. Ministry of Health, Labour and Welfare of Japan. No. 285, 2011.

14) Hayashi E, Kishimoto $Y$, Tada K, Kudo T, Sekiba K. Fetal and neonatal excretion of free and conjugated ritodrine. Acta Med Okayama. 1992; 46 (6) : 443-8.

15) Brashear WT, Kuhnert BR, Wei R. Maternal and neonatal urinary excretion of sulfate and glucuronide ritodrine conjugates. Clin Pharmacol Ther. $1988 ;$ 44(6) : 634-41.

16) Brashear WT, Kuhnert BR, Wei R. Structural determination of the conjugated metabolites of ritodrine. Drug Metab Dispos. 1990; 18(4) : 488-93.

17) Pacifici GM, Kubrich M, Giuliani L, de Vries M, Rane A. Sulphation and glucuronidation of ritodrine in human foetal and adult tissues. Eur $J$ Clin Pharmacol. 1993; 44(3) : 259-64.

18) Kuhnert BR, Gross TL, Kuhnert PM, Erhard P, Brashar WT. Ritodrine pharmacokinetics. Clin Pharmacol Ther. 1986; 40 (6) : 656-64.

19) Freysz H, Willard D, Lehr A, Messer J, Boog G. A long term evaluation of infants who received a beta-mimetic drug while in utero. $J$ Perinat Med. 1977; 5(2) : 94-9.

20) Brosset P, Ronayette D, Pierre MC, le Lorier B, Bouquier JJ. Cardiac complications of ritodrine in mother and baby. Lancet. 1982; 1 (8287) : 1468.

21) Hermansen MC, Johnson GL. Neonatal supraventricular tachycardia following prolonged maternal ritodrine administration. Am J Obstet Gynecol. 1984; 149(7): 798-9. 